\title{
TAXABILITY OF SCHOLARSHIPS AND FELLOWSHIP GRANTS*
}

\author{
Paul J. Werss, JR. $\dagger$
}

I

INTRODUCTION

THE OBJECTIVE of this paper is to set forth in as comprehensive a manner as possible the present status ${ }^{2}$ of the law with respect to the taxability of scholarship and fellowship grants. It should be recognized at the outset that the issue is not one of infrequent occurrence. In fact, in spite of the avowed purpose of Congress in enacting section 117 of the Internal Revenue Code of 1954, whinch provides "rules for determining the extent to which amounts received as scholarships and as fellowship grants are to be included in gross income," it has been stated that its enactment, rather than stabilizing the law and reducing controversies, has in fact resulted in an increase in disputes between the Commissioner and recipients of such awards. Professor Donald $\mathrm{H}$. Gordon has stated that

[I] one compares the cases and rulings under the 1954 Code with those under pre-1954 law, one sees that there has been little change of focus.... The value of section 117 lies not in providing a solution to the problem but rather in its recognition that scholarships and fellowships are sufficiently unique in terms of their social function ... to merit treatment separate from that accorded gifts and compensation. ${ }^{3}$

One writer charges that the present application of section 117 is

- The views expressed are the author's and should not be considered as being the opinion of the Treasury Department, the Internal Revenue Service, or the Chief Counsel's Office.

†A.B. 1944, University of Florida; LL.B. 1950, University of Michigan; Assistant Regional Counsel, Atlanta Region, Internal Revenue Service.

IThe underlined words were chosen in lieu of the words "a clarification or simplification" as the latter is well nigh impossible. The reader will no doubt so conclude after reading this paper. 1622].

${ }^{2}$ S. REP. No. 1622. 83d Cong., 2 d Sess. 17 (1954) [hereinafter cited as S. REP. No.

3 Gordon, Scholarships and Fellowship Grants as Incone: A Search for Treasury Policy, 1960 WAsh. U.L.Q. 144, 151. See also 13 J. TAX.ation 272 (1960). 
creating "new dissatisfaction" with taxation in this area." Professor Gordon is of the view that while the enactment of section 117 was designed to relieve prior uncertainties, such grants have been "more severely" treated than they, were prior to the enactment of the section.

\section{II}

\section{Status of the LAW UNDER THE 1939 Code}

The Internal Revenue Code of 1939 contained no provision comparable to section 117. Under the 1939 Code the test for determining whether scholarships and fellowship grants were excludable from gross income was based upon the so-called "gift v. compensation" theory, i.e., if it could be shown that the amounts received were, in fact, gifts under section 22 (b) (3) of the 1939 Code, the recipient did not have to include them in his gross income; if such grants were determined to be in the nature of compensation, then the result was to the contrary. ${ }^{\circ}$ The test apparently was similar to that used in determining the taxability of prizes and awards.

\section{A. The Commissioner's Apparent Effort to Clarify the Law}

In 1951 an effort was made by the Internal Revenue Service to clarify the Commissioner's position with regard to scholarships and fellowship grants through promulgation of Income Tax Ruling 4056. ${ }^{7}$ In essence, this ruling provided:

The amount of a grant or fellowship award is includible in gross income unless it can be established that such amount is a gift. If a grant or fellowship award is made for the training and education of an individual, either as a part of his program in acquiring a degree or in otherwise furthering his educational development, no services being rendered as consideration therefor, the amount of the grant or award is a gift which is excludable from gross income. However, when the recipient of a grant or fellowship applies his skill and training to advance research, creative work, or some other project or activity, the essential elements of a gift as contemplated by section 22 (b) (3) of the Internal Revenue Code are not present, and the amount of the grant or fellowship is includible in the recipient's gross income. (Emphasis added.)

\footnotetext{
- Mansfield, Income from Prizes and Awards and from Scholarships and Fellowship Grants, N.Y.U. 19th INST. ON FED. TAX 146 (1961).

See Gordon, supra note 3, at $15 \mathrm{I}$.

- See 1 Mertens, Law of Federal Income Taxation $\$ 7.42$ (1962 rev.).

7 I.T. Rul. 4056, 1951-2 Cukr. Bur.. 8, 10 [hereinafter cited as I.T. 4056].
} 
I.T. 4056 sets forth four examples involving recipients of fellowship grants. In three of the cases the fellowships were granted in order that each recipient could conduct independent research in his chosen field. In the fourth case the fellowship was granted in order to provide the recipient with a source of funds upon which to exist while he was in the process of writing a novel. Although the facts of each case as set forth in I.T. 4056 were somewhat sketchy, the Commissioner took the position that in no case were the grants for the training or education of the recipients, but rather each recipient was required by the grantor, in exchange for the grant, to apply his respective skill and training to advance research or creative work. Accordingly, on the authority of United States $v$. Robertson, ${ }^{8}$ which was affirmed by the Supreme Court ${ }^{9}$ after publication of I.T. 4056, the Commissioner held that the grants were not excludable from gross income as gifts under 1939 Code section 22 (b) (3), but were includable in gross income as compensation for personal services under section 22 (a). The Robertson case involved an award to Robertson for having composed the most outstanding symphony of those submitting entries. Thus, in promulgating its ruling with respect to the recipients of fellowships, the Commissioner relied principally upon a case involving an award for outstanding creative work, a case clearly falling in the "prizes and awards" category.

Parenthetically, it is interesting to note that in Robertson the Supreme Court adhered to the rigid position that all services which are performed in exchange for compensation are employment services. The Court stated it thus:

The discharge of legal obligations-the payment for services rendered or consideration paid pursuant to a contract-is in no sense a gift. . . . Where the payment is in return for services rendered, it is irrelevant that the donor derives no economic benefit from it. (Emphasis added.)

In the case of the four fellowships involved in I.T. 4056 the Commissioner reasoned:

It seems apparent that the awards herein considered were granted on the basis of the qualifications of the recipients to do the work required by their projects, which projects were approved by. the $M$ Foundation with the expectation of results consistent with the recipients' qualifications. To the extent that there is any donative intent present in the making of an

s 190 F.2d 680 (10th Cir. 1951).

- Robertson v. United States, 343 U.S. 711 (1952). 
award, it appears that the beneficiary is society at large and not the recipient of the award whose services are expected in return for the grant. (Emphasis added.)

A careful reading of I.T. 4056 discloses that the Commissioner was simply taking the position that the activities of the four recipients involved were more in the nature of compensation than they were in the nature of gifts. Thus, it has been argued that the Commissioner's apparent effort to clarify the law through I.T. 4056 was really no clarification at all but simply an application of the timeworn "gift $v$. compensation" test to the specific cases involved.

\section{B. The Celebrated Stone Case}

Three years later a recipient of a Guggenheim grant, George $W$. Stone ${ }^{10}$ who was dissatisfied with the state of the law as above expressed, litigated the issue and won a decision from a divided Tax Court. Stone had been awarded a fellowship grant of $\$ 3,000$ for the period from September 1950 to August I951 for the purpose of allowing him to devote his full time and energies to research for and the preparation of an eight-volume work on the history of London dramatic performances from 1660 to 1800 . Stone's research was in a field of his own selection. The arrangement between the foundation and Stone was not an employment contract in the sense that the foundation did not (l) retain the authority to direct and control Stone as to the details and means by which the project was carried out; (2) require conformity with a schedule of working hours; (3) supervise the work to see that it was carried out in a satisfactory manner; or (4) require reports on Stone's progress or even his completion of the task. In one sense, he was under no obligation to perform services for the foundation or for any other person. He nonetheless represented to the grantor that he would undertake the project outlined and it was upon the basis of this representation that the grantor agreed to award him the grant. The majority of the court concluded that the grant was to facilitate the further education or training of the recipient and thus was excludable from his gross income.

1023 T.C. 254 (1954). 
C. Stone Pinpoints the Difficulty in Applying the

Commissioner's Test

It will be noted that the test applied by the majority in Stonethat the grant was to facilitate the further education or training of the recipient-accords with the first half of the pronouncement by the Commissioner in I.T. 4056: "If a grant or fellowship award is made for the training and education of an individual, either as a part of his program in acquiring a degree or in otherwise furthering his educational development," the same is excludable from gross income. When the minority opinion of Judge Turner is studied, it is apparent that the minority would disallow the exclusion for the reason that Stone was in effect "applying his skill and training to advance research, creative work or some other project or activity"11 in exchang $\mathrm{e}$ for the grantor's promise to pay the award. This reasoning follows the concept espoused in the latter portion of I.T. 4056.

Recipients of such awards have argued that the case points up the dilemma confronting them in that as a practical matter the recipient's activity in most cases can be said to fit nicely into either slot, i.e., the recipient can be furthering his education and training and at the same time be applying his skill or training to advance research, creative work, or some other project or activity in exchange for the grant. The concepts are not mutually exclusive.

Congress was cognizant of this unsatisfactory state of things when it was in the process of promulgating section 117 of the 1954 Code. Congress recognized that the Internal Revenue Service had "not provided a clear-cut method"12 of determining taxability, and it sought to provide rules ${ }^{13}$ in enacting section 117 to stabilize the law in this area.

\section{III}

Status of the Law Under the 1954 Code

An examination of section 117 and the Treasury Regulations ${ }^{14}$ relating thereto reveal that neither is voluminous, the former consisting of one page and the latter of five.

The statute first provides that in the case of an individual, gross

12 I.T. 4056.

12 S. REP. No. 1622.

18 Ibid.

14 Hereinafter cited as Regulations or Regs. 
income does not include any amount received as a scholarship at an educational institution (as defined in section 151 (e) (4) of the 1954 Code) or any amount received as a fellowship grant, including the value of contributed services and accommodations. It is then provided that any amounts received to cover expenses for travel, ${ }^{15}$ research, clerical help or equipment, ${ }^{16}$ which are incident to the scholarship or fellowship grant (to the extent so expended by the recipient for such purpose) are likewise excludable.

\section{A. Definition of Scholarships}

At this point it is noteworthy to examine the definition of scholarships and fellowship grants as set forth in regulations. A scholarship is said to mean an amount paid or allowed to, or for the benefit of, a student, whether an undergraduate or a gradaute, to aid such individual in pursuing his studies. The term includes the value of contributed services and accommodations as well as any fees or charges for matriculation, tuition, or the like. In addition, an amount received in the nature of a family allowance as a part of the scholarship is said to be includable. However, it "does not include any amount provided by an individual to aid a relative, friend, or other individual ... where the grantor is motivated by family or philanthropic considerations." ${ }^{17}$

\section{B. Definition of Fellowship Grants}

The definition of fellowship grants contained in regulations section $1.117-3$ (c) is substantially the same as the foregoing. As a practical matter, it can properly be said that "fellowship grants" generally apply to graduate students. "Scholarships" as a matter of word usage is the all-inclusive generic term applicable to financial aid to all students. ${ }^{18}$

Under both definitions, however, the regulations ${ }^{19}$ state that among the items not considered as scholarships and fellowship grants are amounts which represent compensation for past, present or future

\footnotetext{
${ }^{15}$ Including meals and lodging while traveling and an allowance for travel of the recipient's family. Regs. $\$ 1.117-1$ (b) (1).

${ }^{10}$ In the case of a grant awarded after July 28, 1956, the exclusion for travel, research, clerical help or equipment is inapplicable unless the amount received is specifically designated to cover such expenses. Regs. $\$ 1.117-1$ (b) (2) (i).

${ }^{17}$ Regs. \$1.117-3 (a).

19 P-H TAX IDEAS ๆ5017.2 (1959).

${ }^{10}$ Regs. $\$ 1.117-4(c)$.
} 
employment service, or amounts which represent payment for services which are subject to the direction or supervision of the grantor,. or which enable the recipient to pursue studies or research primarily for the benefit of the grantor. This rather broad rule is said not to apply, however, if the primary purpose of the studies or research is to further the education and training of the recipient in his individual capacity and the amount provided by the grantor for such. purpose does not represent compensation for past, present or future. employment services or services which are subject to the direction or supervision of the grantor.

Moreover, neither the fact that the recipient is required to furnish reports of his progress to the grantor nor the fact that the results of his studies or research may be of some incidental benefit to the grantor shall, of itself, be considered to destroy the essential character of such amount as a scholarship or fellowship grant.

\section{Limitations On Exclusion-Degree Candidates}

Having become familiar with the broad general exclusionary rule and having examined the more precise regulatory definitions of scholarships and fellowship grants, consideration should be given to the statutory limitation imposed in determining whether the award qualifies for income exclusion.

At the outset it must be emphasized that in the case of a scholarship the award must be for the purpose of enabling the recipient to pursue studies at an "educational institution." The Code provision refers to section 151 (e) (4) where such an institution is defined as a school having a regular faculty and curriculum and an organized student body in attendance. ${ }^{20}$ Apparently the recipient need not attend the same institution which is the grantor of the award, i.e., the award could be made under a corporation's scholarship program for study at any qualified educational institution.

In the case of recipients who are candidates for degrees the Code and regulations provide only one limitation. Generally, amounts received as payment for teaching, research or other services in the nature of part-time employment required as a condition to receiving the award are included in the recipient's gross income. Even in this case said amounts will be fully excludable if such services are uniformly required of all such degree candidates. An example of this

${ }^{20}$ See also Regs. $\$ 1.117-3$ (b). 
limitation is the case where an individual receiving an award is required to teach part-time and this requirement is a condition precedent to receiving the award. The criterion for determining how much to include in gross income is what is usually paid for similar services to an individual who is not an award recipient. If the recipient of the grant is required to furnish periodic reports to the grantor regarding his progress this alone would not constitute part-time employment. Thus, it would not disqualify any portion of the award and the excludable feature would prevail..21

D. Limitations On Exclusion-Non-degree Candidates

The limitations upon those recipients who are not candidates for a degree are very precisely defined. First, there is a basic requirement that the grantor be a tax exempt organization described in section 501 (c) (3) or it must be the United States or an instrumentality or agency thereof, or a state, a territory, or a possession of the United States or any political subdivision thereof, or the District of Columbia. For years beginning after December 31, 1961, grants from foreign governments, international organizations, or foundations or commissions created or continued under the Mutual Educational and Cultural Exchange Act of 1961 are likewise excludable. ${ }^{22}$

To qualify as a tax exempt organization under section 501 (c) (3) the grantor must meet four tests:

1. It must be organized and operated exclusively for one or more specific purposes, e.g., religious, charitable, scientific, educational, etc.

2. It must not have any part of its net earnings inure to the benefit of any private shareholder or individual.

3. It must not devote a substantial part of its activities attempting to influence legislation.

4. It may not participate or intervene in any political campaign on behalf of any candidate for public office.

Thus, awards or grants to non-degree candidates made by a business corporation or by an individual would be wholly taxable. This, of course, necessitates a determination as to whether the actual

\footnotetext{
${ }^{21}$ Regs. \$1.117-2 (a) (1).

22 INr. REv. CODE OF 1954, $\$ 117$ (2), as amended by Pub. L. No. 87-256, 87th Cong., 2d Sess. $\$ \S 110(\mathrm{a}), 110(\mathrm{~h})(\mathrm{l})$ (Sept. 21, 1961).
} 
payor is the grantor or is possibly merely the paying agent for a grantor.

In this connection it should not be overlooked that in many cases an award though it may not qualify as an exclusion under section 117 nevertheless may be deductible by the recipient as an educational expense, ${ }^{23}$ a subject beyond the scope of this paper.

After it has been established that the grantor qualifies there is a limitation as to the amount that can be excluded by a non-degree recipient. Under section 117 (b) (2) (B), the amount is limited to $\$ 300$ a month for a maximum period of 36 months.

It is first necessary to determine the period of the grant. The number of months is computed on the basis of whole calendar months. A whole calendar month is defined as "a period of time terminating with the day of the succeeding month numerically corresponding to the day of the month of its beginning, less one, except that if there be no corresponding day of the succeeding month the period terminates with the last day of the succeeding mouth."24 A fractional part of a calendar month consisting of at least 15 days is treated as a.whole calendar month. A period of less than 15 days is disregarded.

Example 1. A recipient receives a grant which is to run from September 11 to May 10 of the following year. The length of the grant is 8 months. If, however, the grant ran from September 11 to May 25 its length would be 9 months.

The $\$ 300,36$-month limitation applies if the individual has received any amount (either excluded or excludable) for any previous 36 months, whether or not consecutive. Once used up the grantee is not entitled to any further exclusions as a non-degree recipient. It would seem, however, that he would be eligible for exclusions for awards granted him as a candidate for a degree.

Example 2. A recipient receives a three-year grant of $\$ 9,000$ which was paid in 36 monthly installments of $\$ 250$ each. He has used up his allowable exclusions even though he received $\$ 50$ a month less than the maximum.

Where an individual receives more than one grant during the taxable year the amount excludable from gross income is based on the aggregate amount received. If the period of time of the grants

${ }^{2}$ Regs. $\$ 1.162-5$.

${ }^{24}$ Regs. \$ 1.117-2 (b) (2) (i). 
overlaps, the months are counted only once; they are not compounded.

Example 3. A recipient receives a grant from $A$ of $\$ 350$ per month to run from February 1 to June 30 of one taxable year. $\mathrm{He}$ also receives from $\mathrm{B}$ a grant of $\$ 200$ per month to run from March I to December 31 of the same taxable year. In this instance he is treated as having received amounts for 11 months of the taxable year. His maximum exclusion would thus be $\$ 3,300$ ( $\$ 300 \times 11)$. Since, however, he has received $\$ 3,750$ from both grants he must include $\$ 450$ in gross income. His future excludable balance would be $\$ 300$ a month for 25 months.

Suppose a recipient received a grant for a period covering two taxable years. What is the tax treatment?

Example 4. X receives a grant of $\$ 5,600$ to run from October 5 to May 23 of the following year. He receives $\$ 700$ per month from October through May. In this instance he may exclude $\$ 900$ in the former taxable year and $\$ 1,500$ in the latter. He must include in his gross income $\$ 1,200$ in the former taxable year and $\$ 2,000$ in the latter.

Suppose, however, that an individual receives a grant for a period covering two taxable years, but the entire amount is paid in one year.

Example 5. X received his grant of $\$ 5,600$ to run from October 5 to May 23 of the following year as in the last example above. But in this instance he receives the entire $\$ 5,600$ on October 5. Since the $\$ 5,600$ received in the one taxable year is for the full 8-month term of the grant, $X$ may exclude $\$ 2,400(\$ 300 \times 8)$ from his gross income in the taxable year in which he received the funds. The balance of $\$ 3,200 \quad(\$ 5,600-\$ 2,400)$ is includable in his gross income in that same taxable year of receipt. ${ }^{25}$

\section{E. The Exclusive Nature of Section 117}

It is most important to understand that the exclusion from gross income of an amount which is a scholarship or fellowship grant is controlled solely by section 117 . Accordingly, to the extent that such an award exceeds the limitations spelled out hereinabove it is includable in the gross income of the recipient, notwithstanding the provisions of section 102 relating to the exclusion from gross income

${ }^{25}$ All of the foregoing examples were derived from P-H TAX IDEAS If 5017.2 (a discussion of the corresponding examples in the regulations). 
of gifts or section 74 (b) relating to the exclusion from gross income of certain prizes and awards. ${ }^{26}$

\section{F. Regulations Section 1.117-4 (c)}

An analysis of the court decisions and Internal Revenue Service rulings subsequent to the enactment of section 117 will disclose that a substantial percentage of the disputes have centered around regulations section $1.117-4$ (c). This section provides as follows:

1.117-4 Items not considered as scholarships or fellowship grants.

The following payments or allowances shall not be considered to be amounts received as a scholarship or a fellowship grant for the purpose of section 117:

(c) Amounts paid as compensation for services or primarily for the benefit of the grantor.

(l) Except as provided in paragraph (a) of $\S 1.117-2$, any amount paid or allowed to, or on behalf of, an individual to enable him to pursue studies or research, if such amount represents either compensation for past, present, or future employment services or represents payment for services which are subject to the direction or supervision of the grantor.

(2) Any amount paid or allowed to, or on behalf of, an individual to enable him to pursue studies or research primarily for the benefit of the grantor.

However, amounts paid or allowed to, or on behalf of, an individual to enable him to pursue studies or research are considered to be amounts received as a scholarship or fellowship grant for the purpose of section 117 if the primary purpose of the studies or research is to further the education and training of the recipient in his individual capacity and the amount provided by the grantor for such purpose does not represent compensation or payment for the services described in subparagraph ( 1 ) of this paragraph. Neither the fact that the recipient is required to furnish reports of his progress to the grantor, nor the fact that the results of his studies or research may be of some incidental benefit to the grantor shall, of itself, be considered to destroy the essential character of such amount as a scholarship or fellowship grant.

In Frank Thomas Bachmura ${ }^{27}$ an argument was unsuccessfully made to the effect that the regulations erroneously interpret the intent of Congress as expressed in the statute and committee reports. Bachmura, the recipient of a Rockefeller Foundation grant, was a non-degree candidate who devoted three-fourths of his time to research and one-fourth to teaching. Bachmura argued that it

\footnotetext{
so Regs. \$ 1.117-1 (a).
}

${ }^{27} 32$ T.C. 1117 (1959). 
was not intended that in the case of non-degree recipients the fact that a grant is in the nature of compensation for employment services would entirely preclude its exclusion from income. The argument proceeded thus.

The House Report ${ }^{28}$ stated:

In the case of individuals who are not candidates for degrees, the bill provides a specific standard to be used in determining whether the grant is in effect a salary payment. In the case of such individuals, the grant is excluded only. if the annual amount ... plus any compensation received from the recipient's previous employer is less than 75 percent of the recipient's salary in the year preceding the grant.

This will tax those grants which are in effect merely payments of a salary during a period while the recipient is on leave from his regular job. Hence, in the case of persons who have completed their formal education and are continuing to teach or carry on research as part of their life work, the grant will be excluded only if it is merely a supplement to the individual's own funds which make it possible for him to carry on research or further his educational development. (Emphasis added.)

The Senate, in considering the proposed 75 per cent test of the House, indicated that it was of the view that said test could result in inequity, particularly where a recipient might have received an inconsequential salary in a previous year. Accordingly, the 75 per cent test was eliminated and the $\$ 300$ per month, 36 months limitation was substituted therefor. The Senate Report ${ }^{29}$ stated:

The House bill provided a specific standard for determining the taxability of grants received by individuals who are not candidates for a degree, typically the recipients of post-doctoral fellowships. Such grants may. be in effect a continuing salary payment while the recipient is on leave from his regular job. The House bill specified that such grants are excludible only if the annual amount of the grant plus any compensation received from the recipient's previous employer is less than 75 per cent of the recipient's salary in the year preceding the grant. Cases were brought to your committee's attention in which the formula of the House bill would tax grants which were clearly not a continuing salary payment. In many of these cases taxability would result from the absence of a substantial earned income in the previous year. Your committee therefore has substituted for the 75 per cent rule an exclusion of $\$ 300$ per month of grants paid to individuals who are not candidates for degrees. The exclusion will not be allowed beyond a total of 36 ionths. (Emphasis added.)

\footnotetext{
${ }^{28}$ H.R. Rep. No. 1337, 83d Cong., 2d Sess. 17 (1954).
}

${ }^{20}$ S. ReP. No. 1629, at 18. 
Manifestly, the Senate was cognizant of the fact that some of the post-doctoral fellowship grants were, in effect, continuing salary payments. Nonetheless, the Senate chose to include such grants under section 117 in spite of the compensating nature of the grant and simply limit their excludability by the $\$ 300,36$-month test.

It was further argued that the House was well aware of the fact that certain grants, particularly those for the performance of teaching and research services, might well be compensatory in nature. In discussing its proposed section $117(\mathrm{~b})$, the House suggested an allocation of awards in such circumstances as follows:

When the scholarships and fellowships are granted subject to the performance of teaching or research services, the exclusion is not to apply to that portion which represents payments which are in effect a wage or salary. The amount included will be determined by reference to the going rates of pay for similar services. This allocation of the amount of the grant between taxable and nontaxable portions represents more liberal treatment than is allowed under present practice. Present law taxes the grant in its entirety. unless services required of the recipient are nominal. (Emphasis added.)

The Senate, in considering the position of the House, chose to be even more liberal with regard to teaching and research services by non-degree candidates. The House had taken the position that it recognized that payments for teaching and research services constituted compensation and should be taxed at the prevailing rate of compensation for such services. The Senate, however, decided that only degree candidates should be taxed upon payments made for these services. The effect of the Senate Committee amendment, Bachmura argued, was to indicate an intent, by implication if not expressed, that non-degree candidates might receive awards which were continuing salary payments and yet still be held to be covered by section 117 , subject to the $\$ 300,36$-month limitation. The Senate Report stated:30

Subsection (b) [of section 117] prescribes rules limiting the amount which may be excluded under subsection (a). Paragraph (1) of this subsection as passed by the House provided that the exclusion does not apply to any amount which represents payment for teaching or research services in the nature of part-time employment required as a condition to receiving the scholarship or fellowship grant. This paragraph has been

${ }^{30}$ Id. at $188-89$. 
amended by your committee so as to be applicable only to individuals who are candidates for degrees at an educational institution ..." $(\mathrm{Em}$ phasis added.)

Bachmura thus argued that insofar as regulations section 1.117. 4 (c) attempts to preclude the exclusion entirely (and not simply limit it to the $\$ 300,36$-month test) in the case of non-degree candidates, where the services to be performed by the recipient are in the nature of employment services, said regulations may have misinterpreted congressional intent.

\section{G. The Position of the Tax Court}

The position taken by the Tax Court when it was confronted with the foregoing is of interest. The Court summarily disposed of petitioner's argument as follows: ${ }^{31}$

We agree that amounts received as a fellowship grant may be compensatory in character, and that with the enactment of section 117 of the 1954 Code it no longer follows that such amounts are to be included in gross income merely because they were in the nature of compensation for services rendered. But further, we are of the view that respondent's regulation, section $1.117-4$ (c), is not to the contrary, as petitioner contends.

....

It is patent, we think, that Congress never intended that the exclusion provided in section 117 (a) should apply to payments received by an individual not a candidate for a degree merely because they were received from an educational or charitable institution or foundation meeting the requirements as set forth in section 117 (b) (2) (A).

....

According to section 1.117-4(c), payments received, even though to enable the recipient to pursue studies or research, are not to be regarded as amounts received as fellowship grants within the meaning of section 117 and as such excluded from gross income, if the payments represent compensation for what in the regulation has been termed "employment services." On the other hand, the regulation recognizes as excludable under section 117 (a) payments even though compensatory in character, provided they are amounts paid to the individual to enable him to pursue studies or research, if the primary purpose of such studies or research is to further the education and training of the recipient in his individual capacity, and provided they do not represent compensation for "employment services," as previously indicated. It would thus appear that the respondent in his interpretation and application of section 117 has concluded that where in the case of an individual who is not a candidate

\footnotetext{
${ }^{3 x}$ Frank Thomas Bachmura, 32 T.C. 1117, 1125-26 (1959).
} 
for a degree the arrangement between the parties is primarily one of employment and the payments, even though for research, are primarily payments of compensation as such and their primary purpose is not that of enabling the recipient to carry on the studies or research in furtherance of his own education and training, such payments are not to be regarded as amounts received as a fellowship grant within the meaning of section 117. (Emphasis added.)

\section{IV}

\section{CONCLUSTON}

Obviously, the foregoing points up the rather confused state of things and probably justifies the position of Professor Gordon that "the value of section $\mathrm{Il} 7$ lies not in providing a solution to the problem but rather in its recognition that scholarships and fellowships are sufficiently unique . . . to merit treatment separate from that accorded gifts and compensation." 32

That the law in this area is still not free from doubt is quite clear, as witness the numerous rulings and cases pending. Perhaps the best guide line that can be used in attempting to evaluate the merits of any given issue, irrespective of whether a degree or nondegree candidate is involved, is contained in the Government's brief in the case of Chander $P$. Bhalla ${ }^{33}$ and quoted with approval by the court as follows:

It is apparent from the above cited regulations and rulings that whether a payment qualifies as a scholarship or fellowship grant excludable from gross income under section 117 of the 1954 Code depends upon whether the primary purpose of the payment is to further the education and training of the recipient or whether the primary purpose is to serve the interest of the grantor. The problem is usually somewhat difficult of solution because of the fact that in most of the situations there is a dual or mutual benefit involved. The question of necessity must be resolved on a factual basis and depends upon the facts and circumstances in each particular case. (Emphasis supplied by court.)

An objective study of the italicized portion of the above quote could well leave the reader somewhat up in the air. One might properly ask-What, in fact, is the test? Has there really been any change in philosophy on the part of the courts as a result of the enactment of the I954 Code provision?

\footnotetext{
82 Gordon, supra note 3 , at 151 .

3835 T.C. 13,17 (1960).
} 
It is believed that, in spite of the apparent increase in controversies and notwithstanding the charges leveled by various writers as set forth hereinabove, there has been a perceptible change. It is felt that there has been an effort on the part of the courts to liberalize their thinking consistent with the intent of Congress. Clearly, it would seem that the pre-1954 "quid pro quo" test espoused in Robertson ${ }^{34}$ has been watered down to some extent. At least it can be said that if it can be shown that the award is not compensatory in nature and that the grantor has not or will not derive any economic benefit from the services performed by the grantee, there is today more likelihood that the award will be held to be excludable from gross income. In 1952 the Supreme Court in Robertson took the position that "it is irrelevant that the donor derives no economic benefit from" 35 the grantee's services. It is in this sense that one must interpret the phrase "to serve the interest of the grantor" as used by the Tax Court in the above quote from Chander P. Bhalla. ${ }^{36}$

\footnotetext{
sc United States v. Robertson, 190 F.2d 680 (10th Cir. 1951).

${ }^{85}$ Robertson v. United States, 343 U.S. 711, 714 (1952).

so 35 T.C. 13,17 (1960).
} 